\title{
Anti-Müllerian hormone is a gonadal cytokine with two circulating forms and cryptic actions
}

\author{
Ian S McLennan and Michael W Pankhurst
}

Department of Anatomy, University of Otago, PO Box 913, Dunedin 9054, New Zealand

Correspondence should be addressed to I S McLennan Email

ian.mclennan@otago.ac.nz

\begin{abstract}
Anti-Müllerian hormone (AMH) is a multi-faceted gonadal cytokine. It is present in all vertebrates with its original function in phylogeny being as a regulator of germ cells in both sexes, and as a prime inducer of the male phenotype. Its ancient functions appear to be broadly conserved in mammals, but with this being obscured by its overt role in triggering the regression of the Müllerian ducts in male embryos. Sertoli and ovarian follicular cells primarily release $A M H$ as a prohormone (proAMH), which forms a stable complex $\left(\mathrm{AMH}_{\mathrm{N}, \mathrm{C}}\right)$ after cleavage by subtilisin/kexin-type proprotein convertases or serine proteinases.

Circulating $\mathrm{AMH}$ is a mixture of proAMH and $\mathrm{AMH}_{\mathrm{N}, \mathrm{C}}$, suggesting that proAMH is activated within the gonads and putatively by its endocrine target-cells. The gonadal expression of the cleavage enzymes is subject to complex regulation, and the preliminary data suggest that this influences the relative proportions of proAMH and $\mathrm{AMH}_{\mathrm{N}, \mathrm{C}}$ in the circulation. $\mathrm{AMH}$ shares an intracellular pathway with the bone morphogenetic protein (BMP) and growth differentiation factor (GDF) ligands. AMH is male specific during the initial stage of development, and theoretically should produce male biases throughout the body by adding a male-specific amplification of BMP/GDF signalling. Consistent with this, some of the male biases in neuron number and the non-sexual behaviours of mice are dependent on $\mathrm{AMH}$. After puberty, circulating levels of $\mathrm{AMH}$ are similar in men and women. Putatively, the function of $\mathrm{AMH}$ in adulthood maybe to add a gonadal influence to BMP/GDF-regulated homeostasis.
\end{abstract}
Key Words
- Sertoli cells
- whole animal physiology
- development
- female reproduction
- male reproduction

Journal of Endocrinology (2015) 226, R45-R57

\section{Introduction}

Anti-Müllerian hormone $(\mathrm{AMH}$, Müllerian inhibiting substance) is part of the classical pathway for the induction of the male phenotype. It is the testicular secretion that triggers the degeneration of the uterine precursor (Müllerian duct) in male embryos (MacLaughlin \& Donahoe 2004, Josso et al. 2005). When AMH is absent, the Müllerian duct is retained, but $\mathrm{XY} \mathrm{AMH}^{-/-}$individuals are otherwise unambiguously male in appearance.
This created the impression that $\mathrm{AMH}$ had recently evolved to mediate limited male-specific functions. This perception of $\mathrm{AMH}$ has been rapidly changing. AMH has multiple faces. It appears to have both local (paracrine/ autocrine) and circulatory (endocrine) roles in both sexes. The classical actions of AMH are paracrine (van Niekerk \& Retief 1981, Mishina et al. 1996, Visser et al. 2007; Supplementary File, see section on supplementary data

Published by Bioscientifica Ltd 
given at the end of this article), but the identification of its actions outside of the reproductive tract is in its infancy. This review discusses AMH as a hormone and argues that the importance of AMH in the circulation has been overlooked, as it may primarily signal in concert with other members of the TGF $\beta$ superfamily (TGF $\beta-S$ ). When operating in this mode, AMH may produce subtle variation in anatomical and physiological settings, which are only detectable by quantitative studies.

\section{AMH is a gonadal cytokine}

AMH is synthesised in the gonads of all vertebrate species examined to date, including fish (Western et al. 1999, Halm et al. 2007), amphibians (Kodama et al. 2015), birds (Smith et al. 1999, Nishikimi et al. 2000), reptiles (Western et al. 1999, Shoemaker et al. 2007), marsupials (Juengel et al. 2002, Pask et al. 2004, 2010) and eutherian mammals (Josso 1973, Meyers-Wallen et al. 1987, Kuroda et al. 1990, Josso et al. 1993). In fish that do not have Müllerian ducts, AMH regulates the proliferation of germ cells in both sexes (Morinaga et al. 2007). In all vertebrates, the production of $\mathrm{AMH}$ is from the cells that nourish, protect and regulate the germ cells: the Sertoli cells of the testes and the ovarian granulosa cells. This suggests that AMH has ancient roles in phylogeny as a regulator of germ cells (Morinaga et al. 2007). AMH's role as an essential inducer of male sexual differentiation also predates the Müllerian duct. In some species of fish, AMH regulates the differentiation of the gonads into testes, and putatively determines testicular differentiation in birds (Smith \& Sinclair 2004, Morinaga et al. 2007, Wu et al. 2010, Cutting et al. 2013). In mammals, AMH does not affect gonad determination as $\mathrm{XY} \mathrm{AMH}^{-1-}$ individuals have testes (Behringer et al. 1994, Josso et al. 2012), although AMH is required for the normal cellular and biochemical development of the mammalian testis (Mishina et al. 1996, Wu et al. 2005).

The study of AMH in lower vertebrates has centred on its role in gonadal differentiation, and there is little information available regarding the evolution of AMH as a hormone. In fish, the expression of the AMH-specific receptor (AMHR2) appears to be specific to the gonads (Morinaga et al. 2007, Kamiya et al. 2012), suggesting that $\mathrm{AMH}$ did not originally have hormonal action. However, AMH is in the blood of chicken embryos (Hutson \& Donahoe 1983) as well as mammals (see below), suggesting that the endocrine functions of AMH are ancient.

Non-gonadal sites of AMH production have also been reported in fish and mammals (Wang et al. 2005, 2009a,
Halm et al. 2007, Ricci et al. 2010, Poonlaphdecha et al. 2011). No function has been ascribed to these sources of $\mathrm{AMH}$, and the form of the AMH produced by non-gonadal cells has not been examined. In mammals at least, circulating AMH appears to be entirely derived from the gonads, as boys with anorchia lack AMH (Aksglaede et al. 2010) and because serum AMH is undetectable after either orchidectomy (Vigier et al. 1982) or oophorectomy (La Marca et al. 2005, Griesinger et al. 2012).

\section{Circulating levels of AMH are dimorphic}

The levels of AMH in the circulation are broadly conserved between species, with the human pattern summarised in Fig. 1. In most, if not all, vertebrate species the secretion of $\mathrm{AMH}$ from the testis precedes the synthesis of testosterone and other gonadal hormones (Tran et al. 1987, Xavier \& Allard 2003). The levels of AMH in immature males are high relative to those of adult males, and typically extend beyond the regression of the Müllerian duct (in species which have the duct). In mammals, the decrease in circulating AMH levels in males is associated with the pubertal transition. Ovarian production of AMH typically begins later in development, and the levels of AMH in the circulation of females never approach those of immature males. The levels of circulating AMH diminish as females age, and fall to very low levels during reproductive senescence. In post-menopausal women, AMH is typically undetectable. Consequently, $\mathrm{AMH}$ is variably male specific, strongly dimorphic with a male bias, or not dimorphic, depending on the stage of the life cycle (Fig. 1).

\section{Two forms of AMH exist in the circulation}

The AMH gene encodes a theoretical 560 amino acid preproprotein, which is a member of the TGF $\beta$-S (Cate et al. 1986). Cleavage of the amino signal peptide is thought to occur during protein synthesis, giving rise to proAMH $\left(\mathrm{AMH}_{25-560}\right)$. ProAMH can be cleaved at position $451 / 452$ to generate $\mathrm{N}$ - and C-terminus fragments $\left(\mathrm{AMH}_{\mathrm{N}}\right.$ and $\mathrm{AMH}_{\mathrm{C}}$; Cate et al. 1986), which remain associated as a stable non-covalently linked complex $\left(\mathrm{AMH}_{\mathrm{N}, \mathrm{C}}\right)$ (Fig. 2; MacLaughlin et al. 1992, Wilson et al. 1993, Pankhurst \& McLennan 2013). Circulating AMH has recently been discovered to contain a mixture of proAMH, which does not appear to activate AMHR2, and $\mathrm{AMH}_{\mathrm{N}, \mathrm{C}}$, which does (Pankhurst \& McLennan 2013; see MacLaughlin et al. (1992) and di Clemente et al. (2010) for information relating to receptor binding). The implications of this are outlined in the paragraphs below.

Published by Bioscientifica Ltd 

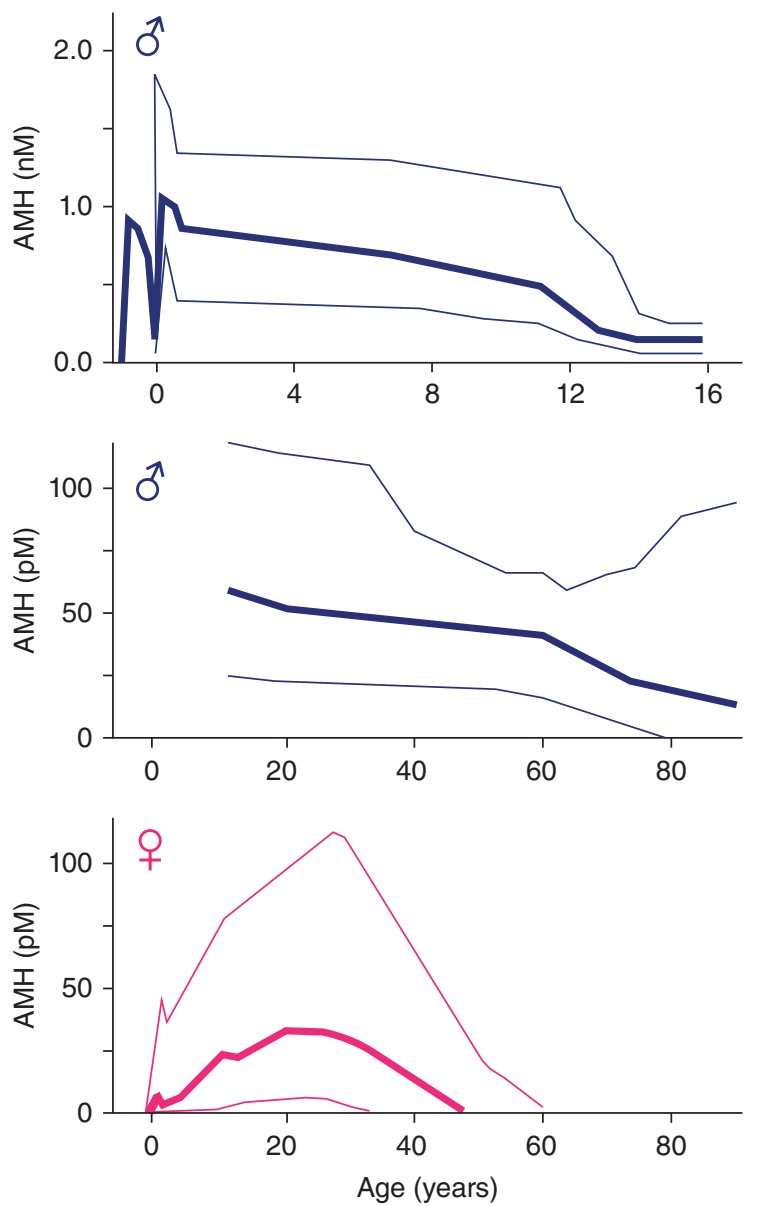

Figure 1

The levels of AMH in the human circulation vary during the life cycle, with a sexually dimorphic pattern. Boys (top panel) and men (middle panel) are presented separately, as the mean levels are so divergent. Females produce little or no AMH in utero. The thick lines illustrate the mean levels, and the thin lines the $95 \% \mathrm{Cl}$. The illustration is based on the following references: Josso et al. (1993), Lee et al. (1996), Schwindt et al. (1997), Rajpert-De Meyts et al. (1999), Rey et al. (1999), Guibourdenche et al. (2003), Oppelt et al. (2005), Aksglaede et al. (2010), Hagen et al. (2010), Grinspon et al. (2011) and Chong et al. (2013). See also Tran et al. (1987), Munsterberg \& Lovell-Badge (1991), Hirobe et al. (1992), Taketo et al. (1993) and Al-Attar et al. (1997) for information on mice and rats.

The C-terminal fragments of TGF $\beta$-S ligands are receptor binding, but they tend to be relatively insoluble in physiological solutions. The formation of $\mathrm{N}$ - and Cterminal complexes increases solubility and facilitates the diffusion of TGF $\beta$-S ligands through biological structures (Mueller \& Nickel 2012). AMH conforms to this pattern with $\mathrm{AMH}_{\mathrm{C}}$ being receptor competent, with the presence of $\mathrm{AMH}_{\mathrm{N}}$ increasing its bioactivity (di Clemente et al. 1992, MacLaughlin et al. 1992, Wilson et al. 1993). Furthermore, the majority of loss-of-function mutations in human $\mathrm{AMH}$ are in the N-terminal domain, emphasising that the non-receptor binding component of AMH has function (Josso et al. 2005). Free $\mathrm{AMH}_{\mathrm{C}}$ has yet to be detected in serum (Pankhurst \& McLennan 2013), suggesting that $\mathrm{AMH}_{\mathrm{N}, \mathrm{C}}$ only dissociates at or near the sites of $\mathrm{AMH}$ action (see also di Clemente et al. (2010)). Experimental studies of AMH have typically used $\mathrm{rAMH}_{\mathrm{C}}$, which may not precisely or invariably mimic $\mathrm{AMH}_{\mathrm{N}, \mathrm{C}}$. Moving forward, we suggest that $\mathrm{rAMH}_{\mathrm{N}, \mathrm{C}}$ should be preferentially used for the experimental analysis of AMH function.

AMH cleavage variants $\left(\mathrm{AMH}_{25-254}\right.$ and $\left.\mathrm{AMH}_{255-560}\right)$ occur in vitro when proAMH is cleaved with a serine protease, such as plasmin (Pepinsky et al. 1988; Fig. 2). $\mathrm{AMH}_{25-254}$ and $\mathrm{AMH}_{255-560}$ are not present at detectable levels in the blood of normal individuals (Pankhurst \& McLennan 2013), but AMH fragments with these characteristics have been observed in the blood of a patient with a sex chord tumour (Ragin et al. 1992) and in equine granulosa cell tumours (Almeida et al. 2011). A putative cleavage site between amino acids 194/195 has been theorised based on sequence similarity with a cleavage site in Glass bottom boat, a Drosophilla TGF $\beta$-S protein (Akiyama et al. 2012). $\mathrm{AMH}_{25-194}$ has not been detected

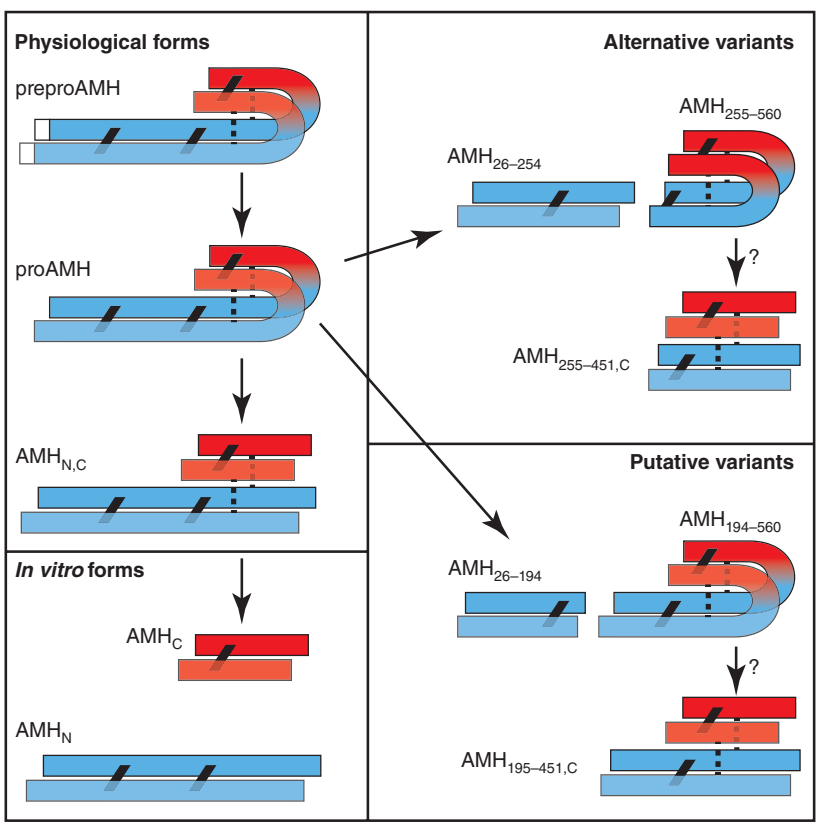

Figure 2

Multiple forms of AMH are generated by post-translational cleavage. The amino acid sequence is numbered from the $\mathrm{N}$-terminus of the preproAMH in this figure and in the text of this paper. Some sources number AMH from the $\mathrm{N}$-terminus of the proAMH. When this numbering system is used, the alternatively cleaved $\mathrm{AMH}_{25-254}$ will be numbered 1-230 and the putative forms will be numbered 1-170 and 171-427.

Published by Bioscientifica Ltd 
in physiological solutions, but naturally occurring mutations of the putative cleavage site in human AMH leads to persistent Müllerian duct syndrome (Imbeaud et al. 1994, Akiyama et al. 2012), the hallmark phenotype of $\mathrm{XY} \mathrm{AMH}^{-1-}$ individuals (Josso et al. 2012). This serves to emphasise that the form of $\mathrm{AMH}$ in the embryonic testes and in the circulation of prenatal males is unknown.

\section{ProAMH levels in the circulation vary}

AMH ELISAs do not discriminate between proAMH and $\mathrm{AMH}_{\mathrm{N}, \mathrm{C}}$ (Pankhurst et al. 2014). The historic information on circulating $\mathrm{AMH}$ is therefore an aggregate measure of two biologically distinct forms of $\mathrm{AMH}$, one of which (proAMH) does not directly activate the canonical AMH receptors. We refer to this aggregate measure as total AMH.

When a prototype proAMH-specific ELISA is used, the ratio between proAMH and $\mathrm{AMH}_{\mathrm{N}, \mathrm{C}}$ in the circulation varies between population groups. ProAMH is most abundant in boys, whereas $\mathrm{AMH}_{\mathrm{N}, \mathrm{C}}$ is the predominant form in men and women. In all age groups, the ratio of proAMH to total AMH varies between individuals (McLennan \& Pankhurst 2014). This raises questions about the physiological meaning of total $\mathrm{AMH}$, as it has an uncertain relationship to the strength of receptor activation. In particular, we note that the pro- and mature forms of some cytokines activate different receptors (e.g. proNGF and NGF: Nykjaer et al. 2004, Hempstead 2014). Furthermore, some cytokine precursors can give rise to multiple distinct hormones through differential cleavage: for example, proopiomelanocortin is variably cleaved to ACTH, $\alpha-, \beta-, \gamma$-MSH, $\beta$-endorphin, CLIP, $\beta$ - and $\gamma$-lipotropin (Takahashi \& Mizusawa 2013). We therefore argue against any presumption that proAMH has no biological activity, unless it is cleaved to $\mathrm{AMH}_{\mathrm{N}, \mathrm{C}}$.

A priori, the relevant physiological measures of $\mathrm{AMH}$ may include the concentration of proAMH, the concentration of $\mathrm{AMH}_{\mathrm{N}, \mathrm{C}}$ and/or the relative levels of proAMH and $\mathrm{AMH}_{\mathrm{N}, \mathrm{C}}$. The latter can be defined as the $\mathrm{AMH}$ prohormone index $(\mathrm{API})=(($ proAMH $) /($ total $\mathrm{AMH}) \times 100)$. As the API decreases, the AMH in the circulation will have a greater ability to activate the canonical AMH pathway, without further processing (see below).

\section{Enzymatic cleavage of proAMH}

Multiple enzymes cleave proAMH in vitro at position 254/255. These include proprotein convertases of the subtilisin/kexin-type 3 (PCSK3) (furin), PCSK5 (PC5 and PC6) and PCSK6 (PACE4) (Nachtigal \& Ingraham 1996), which are PCSK. ProAMH is also cleaved by serine proteinases, most notably plasmin (Ragin et al. 1992). Plasmin dissolves fibrin blood clots, but it also has a proven role in the cleavage of the proforms of cytokines. Plasmin is synthesised as a larger precursor, plasminogen, which is activated by various proteases (plasminogen activators), whose activities in turn are regulated via activators and inhibitors (Ferraris \& Sidenius 2013, Miles $\&$ Parmer 2013). The cleavage of proAMH may therefore be subject to complex regulation in vivo, although this remains to be proven.

\section{Gonadal cleavage of proAMH}

The API may reflect multiple gonadal influences (Fig. 3). Sertoli and granulosa cells express enzymes that cleave proAMH, with the levels of the enzymes and/or their

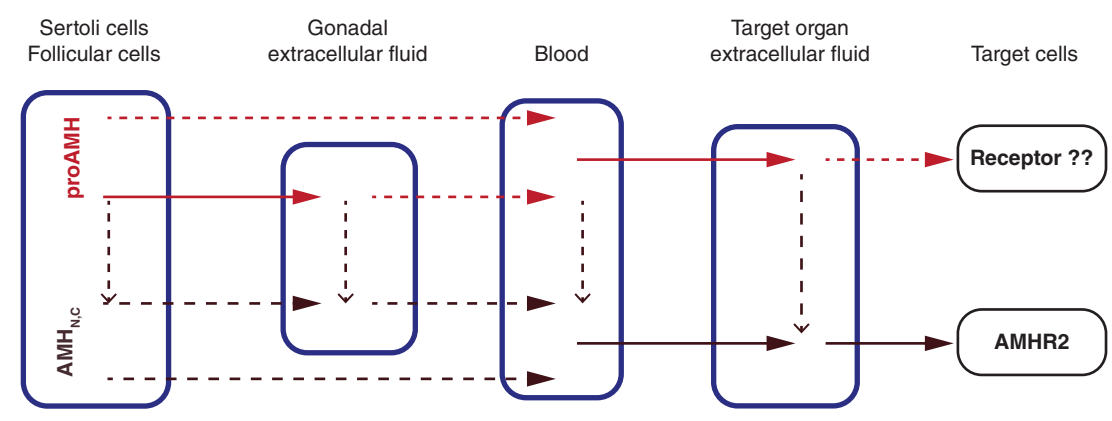

Figure 3

The route between AMH synthesis and receptor activation. The confirmed (solid arrows) and putative (dotted arrows) pathway for proAMH transport and cleavage (side arrows) are illustrated in red. The flow of $\mathrm{AMH}_{\mathrm{N}, \mathrm{C}}$ is illustrated with brown arrows. The figure only illustrates the pathways for endocrine signaling. Sertoli cells release additional AMH into the lumen of the seminiferous tubules, with this $\mathrm{AMH}$ being incorporated into seminal plasma. A proportion of the AMH in the ovarian follicular fluids may be released into the uterine tube during ovulation. 
regulators varying during testicular (Nachtigal \& Ingraham 1996, Guo et al. 2007, Le Magueresse-Battistoni 2007, Uhrin et al. 2007) and ovarian (Bae et al. 2008) development, the seminiferous cycle (Guo et al. 2007, Le Magueresse-Battistoni 2007, Uhrin et al. 2007), the ovarian cycle (Bae et al. 2008, Wang et al. 2014), the stage of ovarian follicular development (Ohnishi et al. 2005, Bae et al. 2008, Antenos et al. 2011) and during pregnancy (Kwok et al. 2013). However, the AMH in ovine follicular fluid is predominantly proAMH with little $\mathrm{AMH}_{\mathrm{N}, \mathrm{C}}$ (Campbell et al. 2012), suggesting that $\mathrm{AMH}$ can be synthesised and released with little or no prior cleavage.

The enzymes that cleave proAMH have extracellular forms (Seidah et al. 2006). The form of AMH within the gonads and within the circulation may therefore depend on the route AMH has taken to reach its current location. For example, the thecal cells of ovarian follicles usually have higher levels of PCSK3 and PCSK5 than do the adjacent granulosa cells, with these levels under gonadotrophin regulation (Bae et al. 2008, Kelty \& Curry 2010). This may alter the form of AMH if the AMH diffuses through the thecal layer. Similarly, AMH produced at one site of the seminiferous tubules or by one ovarian follicle may be cleaved by other parts of the gonad. A key issue here is whether or not the AMH in the circulation is distinct from the $\mathrm{AMH}$ that acts as a paracrine regulator of the gonads. Similarly, AMH is present in semen (Fallat et al. 1996, Fenichel et al. 1999), but it is also unclear whether seminal and circulating $\mathrm{AMH}$ are from a common pool.

\section{Extra-gonadal cleavage of proAMH}

Recombinant proAMH induces regression of the Müllerian duct in organ culture, leading to speculation last century that target tissues can process proAMH (Cate et al. 1986, Wilson et al. 1993). This idea has been in abeyance, but has substantial merit as the putative cleavage enzymes are widely expressed (Villeneuve et al. 1999, Stawowy et al. 2001, Cain et al. 2003, Veinot et al. 2004), under the influence of various physiological and pathological stimuli (Stawowy et al. 2001, Veinot et al. 2004, Marchesi et al. 2011). Under this circumstance, the $\mathrm{AMH}_{\mathrm{N}, \mathrm{C}}$ in circulation defines a basal level of activation, which can be amplified by the local cleavage of proAMH to $\mathrm{AMH}_{\mathrm{N}, \mathrm{C}}$. This is mechanistically similar to testosterone signalling, where activation of the androgen receptor is influenced by circulating levels of testosterone, and by the local conversion of testosterone to the more potent dihydrotestosterone.
Recombinant proAMH is not readily cleaved in human serum in vitro (Pankhurst et al. 2014). However, proAMH-cleaving enzymes are found in vascular tissues (Stawowy et al. 2001, Veinot et al. 2004), and it is therefore possible that proAMH is cleaved to $\mathrm{AMH}_{\mathrm{N}, \mathrm{C}}$ whilst in the circulation. Equally, the cardiovascular system is a putative target for circulating AMH (Appt et al. 2012, Dennis et al. 2013, Yarde et al. 2014), and any cleavage by vascular sources may only have a local effect.

\section{The hallmark function of AMH may be atypical}

$\mathrm{AMH}$ is a phylogenetically ancient protein, whose levels in the circulation are subject to complex regulation during the life cycle in a sexually dimorphic manner (reviewed above). The forms of AMH in the circulation are regulated, with the regulation potentially being very complex (reviewed above). The existence of AMH was detected 99 years ago (Lillie 1916). Despite this, the endocrine functions of AMH are largely unknown. This suggests that the endocrine actions of AMH are cryptic and are being obscured by a misconception(s) about the biology of AMH. Canonically, AMH is an atypical TGF $\beta$-S ligand, which signals in isolation of other members of its family. We alternatively suggest that AMH may be a typical TGFß-S ligand, with the regression of the Müllerian duct being an atypical action for AMH.

\section{TGF $\beta$-S ligands signal interactively}

The TGFß-S ligands signal through complexes consisting of type 1 and type 2 receptors. There are over 30 mammalian TGFß-S ligands, which share five type 2 receptors and seven type 1 receptors. Consequently, TGF $\beta$-S signalling typically arises from the interactions between multiple ligands and multiple receptors (Shi \& Massague 2003, Moustakas \& Heldin 2009). One of the five type 2 receptors (AMHR2) is AMH specific, which is in stark contrast to the superfamily as a whole, which shares the other four receptors. This argument is supported by the observation that $\mathrm{AMH}^{-1-}$ and $\mathrm{AMHR}^{-1-} \mathrm{XY}$ individuals have the same overt phenotype, the persistence of the Müllerian duct (Behringer et al. 1994, Jamin et al. 2002, Josso et al. 2005). This is very strong evidence that $\mathrm{AMH}$ induces regression of the Müllerian duct via AMHR2, independently of other TGF $\beta$-S ligands. However, this does not prove that AMH invariably signals as an isolated regulator, or that AMHR2 is essential for $\mathrm{AMH}$ $\left(\mathrm{AMH}_{\mathrm{N}, \mathrm{C}}\right.$ or proAM) signalling elsewhere in the body. As argued below, AMH may primarily signal in co-operation

Published by Bioscientifica Ltd. 
with other TGF $\beta$-S ligands. Similarly, this evidence does not exclude the possibility that proAMH is able to signal via an unidentified receptor. For example, NGF has a oneto-one relationship with TrkA and the phenotypes of $\mathrm{NGF}^{-1-}$ and TrkA ${ }^{-1-}$ mice were thought to be identical (Carroll et al. 1992, Smeyne et al. 1994) before Sortilin was identified as a proNGF receptor (Nykjaer et al. 2004).

The canonical function of the type 2 receptors is to activate type 1 receptors, which initiate the downstream signalling (Shi \& Massague 2003, Moustakas \& Heldin 2009). AMH does not have a unique type 1 receptor, and to date, there is no evidence for the existence of an AMH-specific intracellular pathway. The AMH-induced regression of the Müllerian duct is mediated by two type 1 receptors (BMPR1A/ALK3 and ACVR1/ALK2), with functional redundancy between the receptors (Orvis et al. 2008). The bone morphogenetic proteins (BMPs) and growth differentiation factors (GDFs) also use these receptors, with the BMP/GDFs constituting more than half of the TGFß-S (Shi \& Massague 2003, Mueller \& Nickel 2012). The three BMP/GDF type 1 receptors activate the SMAD1/5/8 intracellular pathway, which also transduces a proportion of the TGF $\beta$ subfamily (Shi \& Massague 2003, Moustakas \& Heldin 2009; Fig. 4).

Mice with null-mutations of TGF $\beta$-S ligands frequently exhibit limited overt phenotypes (Kingsley et al. 1992, Shull et al. 1992, Kaartinen et al. 1995, Settle et al. 2003),

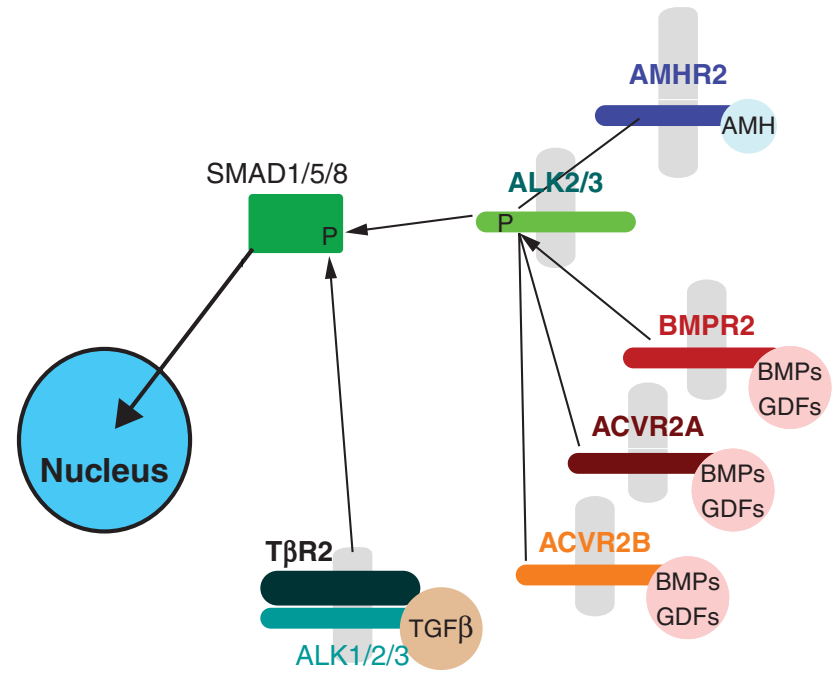

Figure 4

AMH signaling involves elements that are common to other TGF $\beta$-S ligands. The type 1 receptors used by AMH are shared with the BMP and GDF ligands via two type 2 receptors. AMH, BMP and GDF ligands activate the SMAD $1 / 5 / 8$ pathway, along with a minor portion of TGF $\beta$ signalling (based on Shi \& Massague (2003) and Moustakas \& Heldin (2009)). with the full spectrum of their biology only emerging when multiple ligands (Settle et al. 2003, Tilleman et al. 2010) and/or receptors are absent (Oshima et al. 1996, Beppu et al. 2000). Non-redundant signalling appears to occur when a single TGF $\beta-S$ ligand is predominantly or totally activating the common downstream cascade, although non-canonical signalling (Massague 2012) and/or other mechanisms may also contribute to this phenomenon (Mueller \& Nickel 2012). The BMP/GDF ligands bind promiscuously and can activate one or more of three type 2 receptors: BMPR2, ACVR2A and ACVR2b (Shi \& Massague 2003, Mueller \& Nickel 2012). The BMP/GDF ligands and their type 2 receptors are very broadly expressed (Feijen et al. 1994, Lowery \& de Caestecker 2010, Miyazono et al. 2010). The full pattern of AMHR2 expression is still only partially elucidated (see below), but it is possible that the only place where the combination of AMH and AMHR2 is solely activating the SMAD1/5/8 pathway is the Müllerian duct.

\section{AMH may generate sex biases during mammalian development}

When a developing cell expresses AMHR2 and BMPR2, the SMAD1/5/8 pathway would be activated in both sexes via BMPR2, with AMH inducing a male-specific augmentation of this pathway (Fig. 5). A priori, the extent of the sex bias should relate to the relative levels of AMH, BMPs, AMHR2, BMPR2 and associated signalling molecules. If so, AMH may generate a small male bias at one site and large bias at a different location, depending on the local concentrations of BMPs and BMPR2. A similar argument can be made with respect to the other type 2 receptors (Act2R and Act2RB) and ligands which contribute to the activation of the SMAD1/5/8 pathway.

The BMPs, GDFs and the activins contribute to the generation of the basic body plan during embryogenesis, after which they influence the development of most organs, including the brain (Liu \& Niswander 2005, Miyazono et al. 2005, Park et al. 2006, Moustakas \& Heldin 2009, Lowery \& de Caestecker 2010). Consequently, AMH would be expected to produce a male-specific augmentation to numerous developmental processes. This would be expected to induce sex biases, but would not be expected to induce sex-specific biology. Sex biases primarily relate to reproductive fitness.

The biology of sex differences has historically been concerned with the ability to procreate, which requires appropriate sex organs and an ability to recognise the opposite sex. Reproductive fitness extends beyond this.

Published by Bioscientifica Ltd 

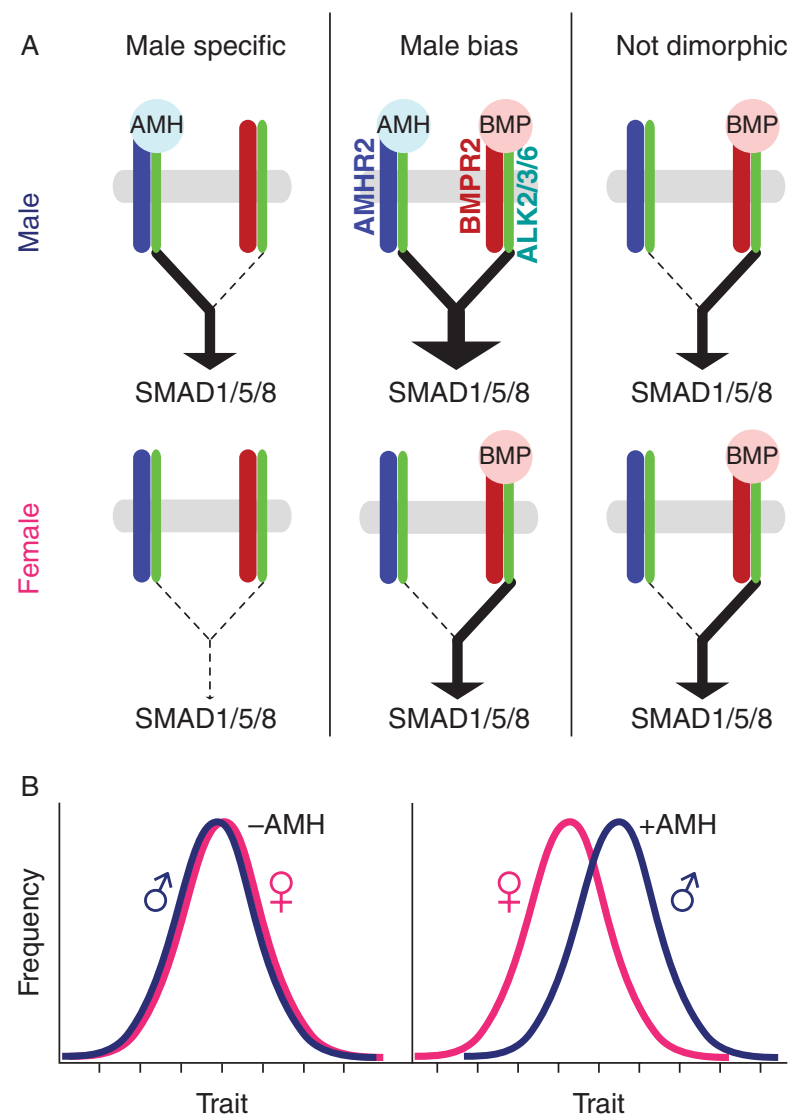

Figure 5

AMH and BMP can combine to produce sex differences. (A) When AMH signals alone (left panel), the SMAD1/5/8 pathway is male specific; when AMH and BMP both signal (middle panel), the SMAD1/5/8 pathway has a male bias; when BMP signals alone, the SMAD1/5/8 pathway is not dimorphic. (B) The left panel illustrates the population distribution for a hypothetical trait under BMP control. The right panel illustrates the hypothetical population distribution produced by AMH and BMP in combination.

It includes subtle quantitative variations in physical and behavioural traits that enhance an individual's ability to compete with other members of their sex. Quantitative sex biases are present in most organs and are common in behaviour, but the bias is typically sufficiently small for the female and male ranges to overlap. Consequently, non-reproductive tissues do not have distinct male or female form, with their characteristics only being sexually dimorphic at the level of the population (when groups of women and men are compared). For example, women on average are shorter than men on average, but the sex of tall women and short men is unambiguous. That is, any deficiency in sex biases would be expected to affect fitness, but is unlikely to alter the perception of the person's sex.
The phenotype of $\mathrm{XY} \mathrm{AMH}^{-1-}$ and AMHR2 ${ }^{-1-}$ mice is consistent with the above mechanism. For example, spinal motor neurons express BMPR2 and AMHR2, with AMH and BMP6 promoting the survival of motor neurons in vitro (Wang et al. 2005, 2007). The number of neurons in the brain is regulated through the control of programmed cell death (Oppenheim 1991). Hence, AMH should induce a male bias in the number of motor neurons. Consistent with this, WT male mice have $16 \%$ more spinal motor neurons than their WT sisters, with this sexual dimorphism being absent in $\mathrm{AMH}^{-1-}$ and $\mathrm{AMHR}^{-1-}$ mice (Wang et al. 2009b). $\mathrm{AMH}^{+/-}$mice exhibit a male bias which is half that of their WT brothers (Wang et al. 2009b). Similar AMH-dependent sex biases have been detected in the numbers of cerebella Purkinje cells (Wittmann \& McLennan 2011) and in the calbindin ${ }^{+v e}$ neurons of the sexually dimorphic nucleus of the preoptic area (Wittmann \& McLennan 2013a) and the bed nucleus of stria terminalis (Wittmann \& McLennan 2013b). The latter two brain nuclei are highly dimorphic in adults, with AMH being only responsible for the sex differences that develop before the onset of puberty (Wittmann \& McLennan 2013a,b). This serves to emphasise that the differences between the sexes is a product of multiple mechanisms (Arnold 2004), of which AMH is but one.

Male $\mathrm{AMH}^{-1-}$ mice prefer to sniff female rather than male bedding, suggesting that they are heterosexual (Wittmann \& McLennan 2013b). However, $\mathrm{AMH}^{-1-}$ male pups exhibit female-like exploration of novel objects (Morgan et al. 2011a), and $\mathrm{AMH}^{-1-}$ adult mice exhibit female-like behaviours when exploring a chamber (Wang et al. 2009b). Both of these behaviours are thought to relate to the propensity of male mice to hold larger territories than female mice, which is a component of reproductive fitness.

Null mutations of AMH and AMHR2 are very rare in humans, and detailed studies of their characteristics are not available. However, putative functions for AMH in humans can be detected by correlating the traits of boys with their levels of AMH. This approach is based on the observations that AMH levels of age-matched boys show high inter-person variation, with this variation being stable over time (Aksglaede et al. 2010, Morgan et al. $2011 b$ ). When this approach is used, the level of a boy's AMH negatively correlates with indexes of his physical (Morgan et al. 2011b) and cognitive development (Morgan et al. 2011c). Boys tend to be less mature than age-matched girls across many traits, and the observed correlations suggest that testicular AMH contributes to this by slowing the speed at which males develop. It is not currently

Published by Bioscientifica Ltd. 
possible to directly test causality here. However, if AMH does slow the rate of human development, then biological theory suggests that boys with high levels of AMH should be less affected by developmental disorders than boys with lower levels of AMH. Consistent with this a priori prediction, the severity of symptoms of boys with an autistic spectrum disorder negatively correlates with their levels of circulating AMH (Pankhurst \& McLennan 2012).

In summary, AMH is an ancient inducer of the male phenotype. It can induce male-specific biology (absence of a uterus), but in mammals the overt male-specific features are mainly the province of testosterone. The predominant role of AMH may be to interact with other TGF $\beta$-S ligands to produce numerous sex biases throughout the body. The initial murine and human data are consistent with this hypothesis, but the available data are very limited. The role of $\mathrm{AMH}$ in shaping the characteristics of boys, and the resulting men, remains largely unexplored.

\section{AMH can signal at adult circulatory levels}

$\mathrm{AMH}$, like other TGF $\beta$-S ligands, has context-dependent dose-response curves. Consequently, the fact that adult men have an order-of-magnitude less circulating AMH than boys do (Fig. 1) is not an a priori reason to presume that $\mathrm{AMH}$ is not a hormone in adults. Embryonic neurons in vitro exhibit a log-linear dose curve, with adult-like levels of AMH producing biologically significant effects (Wang et al. 2005). Embryonic neurons are an order-ofmagnitude more sensitive to AMH than some cell lines (compare Wang et al. (2005) and Masiakos et al. (1999) and Pieretti-Vanmarcke et al. (2006)). The determinants of the dose-response curve for $\mathrm{AMH}$ are unknown, but may include the ability of the target cells to cleave proAMH adjacent to the receptor, as the recombinant $\mathrm{AMH}$ used in most experiments is a mixture of proAMH and $\mathrm{AMH}_{\mathrm{N}, \mathrm{C}}$.

The specificity and dose-response curves of the TGFß-S are a product of binding proteins as well as receptors. The ligand-specificities of the binding proteins can be distinct from those of the receptors, creating interactions between the various TGF $\beta$ subfamilies (Shi \& Massague 2003, Massague 2012). The AMH-induced regression of the Müllerian duct does not require a binding protein, and the influence of binding proteins on $\mathrm{AMH}$ signalling has therefore not been thoroughly examined. Preliminary results indicate that the follistatins increase the response of reporter cells to $\mathrm{AMH}_{\mathrm{N}, \mathrm{C}}$ (Kawagishi et al. 2014). Follistatins are classical inhibitors of the activins (de Kretser et al. 2004, Hedger \& de Kretser 2013), which activate the SMAD2/3 intracellular pathway (Shi \& Massague 2003). Consequently, when follistatins are present, the balance between AMH-induced activation of SMAD1/5/8 and activin-induced activation of SMAD2/3 may be altered, although in vivo work is needed to prove this. Most importantly, the preliminary observation with follistatin re-enforces the notion that $\mathrm{AMH}$ is a typical TGFß-S ligand, and its signalling is therefore context-dependent.

The context dependency of TGF $\beta$-S signalling has multiple causes, one of which is competition between ligands and receptors (Massague 2000, 2012). Consequently, the relative levels of receptors can be important, which leads to yet another unresolved paradox of AMH. The AMH-specific receptor (AMHR2) is the most abundant cytokine receptor in motor neurons, with levels that are much higher than other type 2 receptors and the type 1 receptors. Despite this, the neuronal-levels of AMHR2 are orders-of-magnitude less than occurs in the testes, ovary and Müllerian duct (Wang et al. 2005). The physiological significance of this observation is unclear.

The original studies of the distribution of AMHR2 were set to detect gonad-like levels of AMHR2. This created the false impression that AMH only signalled in the gonads and its associated tissues. The presence of AMHR2 has been rigorously proven in multiple sites, including the nervous system, lungs, mammary glands, uterus and prostate (Catlin et al. 1997, Segev et al. 2000, 2001, 2002, Hoshiya et al. 2003, Renaud et al. 2005, Wang et al. 2005, 2009a,b, Lebeurrier et al. 2008). Similarly, broad expression is detected in mice with a reporter gene driven by the endogenous Amhr2 promoter (AMHR2-Cre-lacZ: Wang et al. 2009b) (IS McLennan \& Dennis NA, unpublished observations). However, the rigorous detection of the cellular location of AMHR2 is currently a limiting problem, as the available anti-AMHR2 antibodies show cross-reactivity in some but not all tissues.

\section{Circulatory AMH may signal reproductive status in adults}

The physiology of circulating AMH in adults is an unwritten book, for which there is not even the briefest outline of the plot. As outlined above, the historic evidence suggested that circulating AMH levels in adults could not signal. The current evidence reverses this situation: AMH is present in the circulation of adults, at levels sufficient to activate its receptors, and its receptors appear to be broadly expressed. One thing is certain: $\mathrm{AMH}$ is not vital in the way that classical hormones are, as

Published by Bioscientifica Ltd. 
$\mathrm{AMH}^{-1-}$ individuals do not show any gross symptoms. However, if AMH signals in the way described above, then symptoms would not be expected. In adults, the TGF $\beta-S$ regulates multiple aspects of homeostasis, through a process that integrates multiple signals. By doing so, the TGF $\beta$-S helps to ensure that the functions of cells reflect both their immediate environment and the status of the body as a whole. The function of AMH in adults may be to add a gonadal influence to this integrative process.

The gonads release multiple hormones in both sexes, which in general signal through different intracellular cascades. The activins and the inhibins are TGF $\beta$-S ligands, which predominantly signal through the SMAD2/3 pathway, whereas the sex steroids and INSL3 signal through other pathways. A priori, it is therefore possible that each of these hormones transmits the same biological information but to different parts of the intracellular cascade. However, the levels of circulating AMH in men show almost no concordance with the levels of the other testicular hormones. This suggests that AMH may transmit different information about the gonads than testosterone and the other testicular protein hormones. The number and state of the germ cells in the gonads is the major determinant of the level of AMH in the circulation. This is most clearly established for females (Visser et al. 2012), but it may also be the case for males, as germ cells regulate Sertoli cells (O'Shaughnessy et al. 2008, Cool et al. 2012, Dabaja et al. 2015). Consequently, AMH is uniquely and ideally placed to convey information about the current and future reproductive capacity of an individual. At this stage, it is difficult to predict how this translates into AMHmediated changes in the properties of cells.

If $\mathrm{AMH}$ is part of BMP signalling, then one way forward is to examine sites of proven BMP regulation. The BMPs are broad regulators of the cardiovascular system, with some BMP ligands being putative cardiovascular hormones (Lowery \& de Caestecker 2010). Initial evidence is consistent with the cardiovascular systems as being a target tissue for AMH. The levels of circulating AMH in men associate with the size of their aorta (Dennis et al. 2013). AMH levels on average differ between men with defined cardiovascular conditions (Dennis et al. 2013), with AMH also being linked to pregnancy-associated hypertension (Shand et al. 2014). In female rhesus monkeys, premenopausal AMH levels associate with subsequent atherosclerosis (Appt et al. 2012). However, to date, there has been no experimental examination of whether AMH can directly influence any cardiovascular parameter.

\section{Conclusion}

AMH is a hormone/cytokine that has been trapped by its name and the history of its discovery. If AMH is viewed as the gonadal BMP, it changes from being an atypical cytokine with a few specialised functions to a broad pleiotropic regulator which changes with the stage of life. Initially it may create diversity within the male lineage. As mammals transition into adulthood, AMH may become a signal to the body about the capacity/characteristics of the gonads, with this signal being of relevance to both sexes.

\section{Supplementary data}

This is linked to the online version of the paper at http://dx.doi.org/10.1530/ JOE-15-0206.

\section{Declaration of interest}

I S M and $M$ W P have IP relating to immunoassays that detect specific forms of $\mathrm{AMH}$.

\section{Funding}

The research of the authors is funded by the Health Research Council, New Zealand (www.hrc.govt.nz/, 14-441). The funders had no role in study design, data collection and analysis, decision to publish or preparation of the manuscript.

\section{References}

Akiyama T, Marques G \& Wharton KA 2012 A large bioactive BMP ligand with distinct signaling properties is produced by alternative proconvertase processing. Science Signaling 5 ra28. (doi:10.1126/scisignal. 2002549)

Aksglaede L, Sorensen K, Boas M, Mouritsen A, Hagen CP, Jensen RB, Petersen JH, Linneberg A, Andersson AM, Main KM et al. 2010 Changes in anti-Müllerian Hormone (AMH) throughout the life span: a population-based study of 1027 healthy males from birth (cord blood) to the age of 69 years. Journal of Clinical Endocrinology and Metabolism 95 5357-5364. (doi:10.1210/jc.2010-1207)

Al-Attar L, Noel K, Dutertre M, Belville C, Forest MG, Burgoyne PS, Josso N \& Rey R 1997 Hormonal and cellular regulation of Sertoli cell antiMüllerian hormone production in the postnatal mouse. Journal of Clinical Investigation 100 1335-1343. (doi:10.1172/JCI119653)

Almeida J, Ball BA, Conley AJ, Place NJ, Liu IK, Scholtz EL, Mathewson L, Stanley SD \& Moeller BC 2011 Biological and clinical significance of anti-Müllerian hormone determination in blood serum of the mare. Theriogenology 76 1393-1403. (doi:10.1016/j.theriogenology.2011.06.008)

Antenos M, Lei L, Xu M, Malipatil A, Kiesewetter S \& Woodruff TK 2011 Role of PCSK5 expression in mouse ovarian follicle development: identification of the inhibin $\alpha$ - and $\beta$-subunits as candidate substrates. PLOS ONE 6 e17348. (doi:10.1371/journal.pone.0017348)

Appt SE, Chen H, Clarkson TB \& Kaplan JR 2012 Premenopausal antiMüllerian hormone concentration is associated with subsequent atherosclerosis. Menopause 19 1353-1359. (doi:10.1097/gme. Ob013e31825b4fe2)

Arnold A 2004 Sex chromosomes and brain gender. Nature Reviews. Neuroscience 5 701-708. (doi:10.1038/nrn1494) 
Bae JA, Park HJ, Seo YM, Roh J, Hsueh AJ \& Chun SY 2008 Hormonal regulation of proprotein convertase subtilisin/kexin type 5 expression during ovarian follicle development in the rat. Molecular and Cellular Endocrinology 289 29-37. (doi:10.1016/j.mce.2008.04.006)

Behringer RR, Finegold MJ \& Cate RL 1994 Müllerian-inhibiting substance function during mammalian sexual development. Cell 79 415-425. (doi:10.1016/0092-8674(94)90251-8)

Beppu H, Kawabata M, Hamamoto T, Chytil A, Minowa O, Noda T \& Miyazono K 2000 BMP type II receptor is required for gastrulation and early development of mouse embryos. Developmental Biology 221 249-258. (doi:10.1006/dbio.2000.9670)

Cain BM, Connolly K, Blum A, Vishnuvardhan D, Marchand JE \& Beinfeld MC 2003 Distribution and colocalization of cholecystokinin with the prohormone convertase enzymes PC1, PC2, and PC5 in rat brain. Journal of Comparative Neurology 467 307-325. (doi:10.1002/cne.10924)

Campbell BK, Clinton M \& Webb R 2012 The role of anti-Müllerian hormone $(\mathrm{AMH})$ during follicle development in a monovulatory species (sheep). Endocrinology 153 4533-4543. (doi:10.1210/en.2012-1158)

Carroll SL, Silos-Santiago I, Frese SE, Ruit KG, Milbrandt J \& Snider WD 1992 Dorsal root ganglion neurons expressing trk are selectively sensitive to NGF deprivation in utero. Neuron 9 779-788. (doi:10.1016/ 0896-6273(92)90040-K)

Cate RL, Mattaliano RJ, Hession C, Tizard R, Farber NM, Cheung A Ninfa EG, Frey AZ, Gash DJ, Chow EP et al. 1986 Isolation of the bovine and human genes for Müllerian inhibiting substance and expression of the human gene in animal cells. Cell 45 685-698. (doi:10.1016/ 0092-8674(86)90783-X)

Catlin EA, Tonnu VC, Ebb RG, Pacheco BA, Manganaro TF, Ezzell RM, Donahoe PK \& Teixeira J 1997 Müllerian inhibiting substance inhibits branching morphogenesis and induces apoptosis in fetal rat lung. Endocrinology 138 790-796.

Chong YH, Dennis NA, Connolly MJ, Teh R, Jones GT, van Rij AM, Farrand S, Campbell AJ \& Mclennan IS 2013 Elderly men have low levels of antiMüllerian hormone and inhibin B, but with high interpersonal variation: a cross-sectional study of the sertoli cell hormones in 615 communitydwelling men. PLoS ONE 8 e70967. (doi:10.1371/journal.pone.0070967)

di Clemente N, Ghaffari S, Pepinsky RB, Pieau C, Josso N, Cate RL \& Vigier B 1992 A quantitative and interspecific test for biological activity of antiMüllerian hormone: the fetal ovary aromatase assay. Development 114 721-727.

di Clemente N, Jamin SP, Lugovskoy A, Carmillo P, Ehrenfels C, Picard JY, Whitty A, Josso N, Pepinsky RB \& Cate RL 2010 Processing of antiMüllerian hormone regulates receptor activation by a mechanism distinct from TGF- $\beta$. Molecular Endocrinology 24 2193-2206. (doi:10. 1210/me.2010-0273)

Cool J, DeFalco T \& Capel B 2012 Testis formation in the fetal mouse: dynamic and complex de novo tubulogenesis. Wiley Interdisciplinary Reviews. Developmental Biology 1 847-859. (doi:10.1002/wdev.62)

Cutting A, Chue J \& Smith CA 2013 Just how conserved is vertebrate sex determination? Developmental Dynamics 242 380-387. (doi:10.1002/ dvdy.23944)

Dabaja AA, Mielnik A, Robinson BD, Wosnitzer MS, Schlegel PN \& Paduch DA 2015 Possible germ cell-Sertoli cell interactions are critical for establishing appropriate expression levels for the Sertoli cell-specific microRNA, miR-202-5p, in human testis. Basic and Clinical Andrology 25 2. (doi:10.1186/s12610-015-0018-z)

Dennis NA, Jones GT, Chong YH, van Rij AM \& McLennan IS 2013 Serum anti-Müllerian hormone (AMH) levels correlate with infrarenal aortic diameter in healthy older men: is AMH a cardiovascular hormone? Journal of Endocrinology 219 13-20. (doi:10.1530/JOE-13-0125)

Fallat ME, Siow Y, Belker AM, Boyd JK, Yoffe S \& MacLaughlin DT 1996 The presence of Müllerian inhibiting substance in human seminal plasma. Human Reproduction 11 2165-2169. (doi:10.1093/oxfordjournals.humrep.a019070)

Feijen A, Goumans MJ \& van den Eijnden-van Raaij AJ 1994 Expression of activin subunits, activin receptors and follistatin in postimplantation mouse embryos suggests specific developmental functions for different activins. Development 120 3621-3637.

Fenichel P, Rey R, Poggioli S, Donzeau M, Chevallier D \& Pointis G 1999 Anti-Müllerian hormone as a seminal marker for spermatogenesis in non-obstructive azoospermia. Human Reproduction 14 2020-2024. (doi:10.1093/humrep/14.8.2020)

Ferraris GM \& Sidenius N 2013 Urokinase plasminogen activator receptor: a functional integrator of extracellular proteolysis, cell adhesion, and signal transduction. Seminars in Thrombosis and Hemostasis 39 347-355. (doi:10.1055/s-0033-1334485)

Griesinger G, Dafopoulos K, Buendgen N, Cascorbi I, Georgoulias P, Zavos A, Messini CI \& Messinis IE 2012 Elimination half-life of anti-Müllerian hormone. Journal of Clinical Endocrinology and Metabolism 97 2160-2163. (doi:10.1210/jc.2012-1070)

Grinspon RP, Bedecarras P, Ballerini MG, Iniguez G, Rocha A, Mantovani Rodrigues Resende EA, Brito VN, Milani C, Figueroa Gacitua V, Chiesa A et al. 2011 Early onset of primary hypogonadism revealed by serum anti-Müllerian hormone determination during infancy and childhood in trisomy 21. International Journal of Andrology 34 e487-e498. (doi:10.1111/j.1365-2605.2011.01210.x)

Guibourdenche J, Lucidarme N, Chevenne D, Rigal O, Nicolas M, Luton D, Leger J, Porquet D \& Noel M 2003 Anti-Müllerian hormone levels in serum from human foetuses and children: pattern and clinical interest. Molecular and Cellular Endocrinology 211 55-63. (doi:10.1016/j.mce. 2003.09.011)

Guo J, Shi YQ, Yang W, Li YC, Hu ZY \& Liu YX 2007 Testosterone upregulation of tissue type plasminogen activator expression in Sertoli cells: tPA expression in Sertoli cells. Endocrine 32 83-89. (doi:10.1007/ s12020-007-9014-1)

Hagen CP, Aksglaede L, Sorensen K, Main KM, Boas M, Cleemann L, Holm K, Gravholt CH, Andersson AM, Pedersen AT et al. 2010 Serum levels of anti-Müllerian hormone as a marker of ovarian function in 926 healthy females from birth to adulthood and in 172 Turner syndrome patients. Journal of Clinical Endocrinology and Metabolism 95 5003-5010. (doi:10.1210/jc.2010-0930)

Halm S, Rocha A, Miura T, Prat F \& Zanuy S 2007 Anti-Müllerian hormone $(\mathrm{AMH} / \mathrm{AMH})$ in the European sea bass: its gene structure, regulatory elements, and the expression of alternatively-spliced isoforms. Gene 388 148-158. (doi:10.1016/j.gene.2006.10.018)

Hedger MP \& de Kretser DM 2013 The activins and their binding protein, follistatin - diagnostic and therapeutic targets in inflammatory disease and fibrosis. Cytokine \& Growth Factor Reviews 24 285-295. (doi:10.1016/j.cytogfr.2013.03.003)

Hempstead BL 2014 Deciphering proneurotrophin actions. Handbook of Experimental Pharmacology 220 17-32. (doi:10.1007/978-3-642-45106-5_2)

Hirobe S, He WW, Lee MM \& Donahoe PK 1992 Müllerian inhibiting substance messenger ribonucleic acid expression in granulosa and Sertoli cells coincides with their mitotic activity. Endocrinology 131 854-862.

Hoshiya Y, Gupta V, Segev DL, Hoshiya M, Carey JL, Sasur LM, Tran TT, Ha TU \& Maheswaran S 2003 Müllerian inhibiting substance induces NFkB signaling in breast and prostate cancer cells. Molecular and Cellular Endocrinology 211 43-49. (doi:10.1016/j.mce.2003.09.010)

Hutson JM \& Donahoe PK 1983 Is Müllerian-inhibiting substance a circulating hormone in the chick-quail chimera? Endocrinology 113 1470-1475. (doi:10.1210/endo-113-4-1470)

Imbeaud S, Carre-Eusebe D, Rey R, Belville C, Josso N \& Picard JY 1994 Molecular genetics of the persistent Müllerian duct syndrome: a study of 19 families. Human Molecular Genetics 3 125-131. (doi:10.1093/hmg/ 3.1.125)

Jamin SP, Arango NA, Mishina Y \& Behringer RR 2002 Genetic studies of MIS signalling in sexual development. Novartis Foundation Symposium 244 157-164.

Josso N 1973 In vitro synthesis of Müllerian-inhibiting hormone by seminiferous tubules isolated from the calf fetal testis. Endocrinology 93 829-834. (doi:10.1210/endo-93-4-829) 
Josso N, Lamarre I, Picard JY, Berta P, Davies N, Morichon N, Peschanski M \& Jeny R 1993 Anti-Müllerian hormone in early human development. Early Human Development 33 91-99. (doi:10.1016/0378-3782(93)90204-8)

Josso N, Belville C, di Clemente N \& Picard JY 2005 AMH and AMH receptor defects in persistent Müllerian duct syndrome. Human Reproduction Update 11 351-356. (doi:10.1093/humupd/dmi014)

Josso N, Rey R \& Picard JY 2012 Testicular anti-Müllerian hormone: clinical applications in DSD. Seminars in Reproductive Medicine 30 364-373. (doi:10.1055/s-0032-1324719)

Juengel JL, Whale LJ, Wylde KA, Greenwood P, McNatty KP \& Eckery DC 2002 Expression of anti-Müllerian hormone mRNA during gonadal and follicular development in the brushtail possum (Trichosurus vulpecula). Reproduction, Fertility, and Development 14345-353. (doi:10.1071/RD02027)

Kaartinen V, Voncken JW, Shuler C, Warburton D, Bu D, Heisterkamp N \& Groffen J 1995 Abnormal lung development and cleft palate in mice lacking TGF- $\beta 3$ indicates defects of epithelial-mesenchymal interaction. Nature Genetics 11 415-421. (doi:10.1038/ng1295-415)

Kamiya T, Kai W, Tasumi S, Oka A, Matsunaga T, Mizuno N, Fujita M, Suetake H, Suzuki S, Hosoya S et al. 2012 A trans-species missense SNP in Amhr2 is associated with sex determination in the tiger pufferfish, Takifugu rubripes (fugu). PLoS Genetics 8 e1002798. (doi:10.1371/ journal.pgen.1002798)

Kawagishi Y, Pankhurst MW \& McLennan IS 2014 TGF $\beta$ superfamily binding proteins may modulate AMH signaling. Poster presented at the American Society for Cell Biology/International Federation of Cell Biology Annual Meeting, 6-10 December 2014, Philadelphia, PA, USA. Poster P464.

Kelty BP \& Curry TE Jr 2010 Ovarian furin (proprotein convertase subtilisin/kexin type3): expression, localization, and potential role in ovulation in the rat. Biology of Reproduction 83 147-154. (doi:10.1095/ biolreprod.109.079947)

Kingsley DM, Bland AE, Grubber JM, Marker PC, Russell LB, Copeland NG \& Jenkins NA 1992 The mouse short ear skeletal morphogenesis locus is associated with defects in a bone morphogenetic member of the TGF $\beta$ superfamily. Cell 71 399-410. (doi:10.1016/0092-8674(92)90510-J)

Kodama M, Suda M, Sakamoto D, Iwasaki T, Matsuo Y, Uno Y, Matsuda Y, Nakamura Y, Maekawa S, Katsu Y et al. 2015 Molecular cloning and characterization of anti-Müllerian hormone (AMH) from the Japanese wrinkled frog, Rana rugosa. Endocrinology 156 1914-1923. (doi:10.1210/ en.2013-2053)

de Kretser DM, Buzzard JJ, Okuma Y, O'Connor AE, Hayashi T, Lin SY, Morrison JR, Loveland KL \& Hedger MP 2004 The role of activin, follistatin and inhibin in testicular physiology. Molecular and Cellular Endocrinology 225 57-64. (doi:10.1016/j.mce.2004.07.008)

Kuroda T, Lee MM, Haqq CM, Powell DM, Manganaro TF \& Donahoe PK 1990 Müllerian inhibiting substance ontogeny and its modulation by follicle-stimulating hormone in the rat testes. Endocrinology 127 1825-1832. (doi:10.1210/endo-127-4-1825)

Kwok SC, Chakraborty D, Soares MJ \& Dai G 2013 Relative expression of proprotein convertases in rat ovaries during pregnancy. Journal of Ovarian Research 6 91. (doi:10.1186/1757-2215-6-91)

La Marca A, De Leo V, Giulini S, Orvieto R, Malmusi S, Giannella L \& Volpe A 2005 Anti-Müllerian hormone in premenopausal women and after spontaneous or surgically induced menopause. Journal of the Society for Gynecologic Investigation 12 545-548. (doi:10.1016/j.jsgi.2005.06.001)

Lebeurrier N, Launay S, Macrez R, Maubert E, Legros H, Leclerc A, Jamin SP, Picard JY, Marret S, Laudenbach V et al. 2008 Anti-Müllerian-hormonedependent regulation of the brain serine-protease inhibitor neuroserpin. Journal of Cell Science 121 3357-3365. (doi:10.1242/jcs.031872)

Lee MM, Donahoe PK, Hasegawa T, Silverman B, Crist GB, Best S, Hasegawa Y, Noto RA, Schoenfeld D \& MacLaughlin DT 1996 Müllerian inhibiting substance in humans: normal levels from infancy to adulthood. Journal of Clinical Endocrinology and Metabolism 81 571-576.

Le Magueresse-Battistoni B 2007 Serine proteases and serine protease inhibitors in testicular physiology: the plasminogen activation system. Reproduction 134 721-729. (doi:10.1530/REP-07-0114)
Lillie FR 1916 The theory of the free-martin. Science 43 611-613. (doi:10.1126/science.43.1113.611)

Liu A \& Niswander LA 2005 Bone morphogenetic protein signalling and vertebrate nervous system development. Nature Reviews. Neuroscience 6 945-954. (doi:10.1038/nrn1805)

Lowery JW \& de Caestecker MP 2010 BMP signaling in vascular development and disease. Cytokine \& Growth Factor Reviews 21 287-298. (doi:10.1016/j.cytogfr.2010.06.001)

MacLaughlin DT \& Donahoe PK 2004 Sex determination and differentiation. New England Journal of Medicine 350 367-378. (doi:10.1056/ NEJMra022784)

MacLaughlin DT, Hudson PL, Graciano AL, Kenneally MK, Ragin RC, Manganaro TF \& Donahoe PK 1992 Müllerian duct regression and antiproliferative bioactivities of Müllerian inhibiting substance reside in its carboxy-terminal domain. Endocrinology 131 291-296.

Marchesi C, Essalmani R, Lemarie CA, Leibovitz E, Ebrahimian T, Paradis P, Seidah NG, Schiffrin EL \& Prat A 2011 Inactivation of endothelial proprotein convertase $5 / 6$ decreases collagen deposition in the cardiovascular system: role of fibroblast autophagy. Journal of Molecular Medicine 89 1103-1111. (doi:10.1007/s00109-011-0776-9)

Masiakos PT, MacLaughlin DT, Maheswaran S, Teixeira J, Fuller AF Jr, Shah PC, Kehas DJ, Kenneally MK, Dombkowski DM, Ha TU et al. 1999 Human ovarian cancer, cell lines, and primary ascites cells express the human Müllerian inhibiting substance (MIS) type II receptor, bind, and are responsive to MIS. Clinical Cancer Research 5 3488-3499.

Massague J 2000 How cells read TGF- $\beta$ signals. Nature Reviews. Molecular Cell Biology 1 169-178. (doi:10.1038/35043051)

Massague J 2012 TGF $\beta$ signalling in context. Nature Reviews. Molecular Cell Biology 13 616-630. (doi:10.1038/nrm3434)

McLennan IS \& Pankhurst ME 2014 Assay for Anti-Müllerian hormone. International Patent Application, WO2014/204327.

Meyers-Wallen VN, Donahoe PK, Manganaro T \& Patterson DF 1987 Müllerian inhibiting substance in sex-reversed dogs. Biology of Reproduction 37 1015-1022. (doi:10.1095/biolreprod37.4.1015)

Miles LA \& Parmer RJ 2013 Plasminogen receptors: the first quarter century. Seminars in Thrombosis and Hemostasis 39 329-337. (doi:10.1055/s-00331334483)

Mishina Y, Rey R, Finegold MJ, Matzuk MM, Josso N, Cate RL \& Behringer RR 1996 Genetic analysis of the Müllerian-inhibiting substance signal transduction pathway in mammalian sexual differentiation. Genes and Development 10 2577-2587. (doi:10.1101/gad.10.20.2577)

Miyazono K, Maeda S \& Imamura T 2005 BMP receptor signaling: transcriptional targets, regulation of signals, and signaling cross-talk. Cytokine \& Growth Factor Reviews 16 251-263. (doi:10.1016/j.cytogfr.2005.01.009)

Miyazono K, Kamiya Y \& Morikawa M 2010 Bone morphogenetic protein receptors and signal transduction. Journal of Biochemistry 147 35-51. (doi:10.1093/jb/mvp148)

Morgan K, Meredith J, Kuo J-YA, Bilkey DK \& McLennan IS 2011 $a$ The sex bias in novelty preference of preadolescent mouse pups may require testicular Müllerian inhibiting substance. Behavioural Brain research 221 304-306. (doi:10.1016/j.bbr.2011.02.048)

Morgan K, Dennis NA, Ruffman T, Bilkey DK \& McLennan IS $2011 b$ The stature of boys is inversely correlated to the levels of their Sertoli cell hormones: do the testes restrain the maturation of boys? PLOS ONE 6 e20533. (doi:10.1371/journal.pone.0020533)

Morgan K, Dennis NA, Ruffman T, Bilkey DK \& McLennan IS 2011c Childhood hormones and maturity: does MIS slow maturation in boys? Oral Presentation delivered at the 17th Biennial Conference of the Australasian Human Development Association, 4-6 July 2011, Dunedin, New Zealand. Paper Session 6, abstract p47. (available at: http://www.otago.ac.nz/ahda2011/docs/ahdaprogramme.pdf)

Morinaga C, Saito D, Nakamura S, Sasaki T, Asakawa S, Shimizu N, Mitani H, Furutani-Seiki M, Tanaka M \& Kondoh H 2007 The hotei mutation of medaka in the anti-Müllerian hormone receptor causes the dysregulation of germ cell and sexual development. PNAS 104 9691-9696. (doi:10.1073/pnas.0611379104) 
Moustakas A \& Heldin CH 2009 The regulation of TGF $\beta$ signal transduction. Development 136 3699-3714. (doi:10.1242/dev.030338)

Mueller TD \& Nickel J 2012 Promiscuity and specificity in BMP receptor activation. FEBS Letters 586 1846-1859. (doi:10.1016/j.febslet. 2012.02.043)

Munsterberg A \& Lovell-Badge R 1991 Expression of the mouse antiMüllerian hormone gene suggests a role in both male and female sexual differentiation. Development 113 613-624.

Nachtigal MW \& Ingraham HA 1996 Bioactivation of Müllerian inhibiting substance during gonadal development by a kex2/subtilisin-like endoprotease. PNAS 93 7711-7716. (doi:10.1073/pnas.93.15.7711)

van Niekerk WA \& Retief AE 1981 The gonads of human true hermaphrodites. Human Genetics 58 117-122. (doi:10.1007/BF00284158)

Nishikimi H, Kansaku N, Saito N, Usami M, Ohno Y \& Shimada K 2000 Sex differentiation and mRNA expression of P450c17, P450arom and AMH in gonads of the chicken. Molecular Reproduction and Development 55 20-30. (doi:10.1002/(SICI)1098-2795(200001)55:1\%3C;20::AIDMRD4\%3E;3.0.CO;2-E)

Nykjaer A, Lee R, Teng KK, Jansen P, Madsen P, Nielsen MS, Jacobsen C, Kliemannel M, Schwarz E, Willnow TE et al. 2004 Sortilin is essential for proNGF induced neuronal cell death. Nature 427 843-848. (doi:10.1038/nature02319)

Ohnishi J, Ohnishi E, Shibuya H \& Takahashi T 2005 Functions for proteinases in the ovulatory process. Biochimica et Biophysica Acta $\mathbf{1 7 5 1}$ 95-109. (doi:10.1016/j.bbapap.2005.05.002)

Oppelt P, Strissel PL, Kellermann A, Seeber S, Humeny A, Beckmann MW \& Strick R 2005 DNA sequence variations of the entire anti-Müllerian hormone $(\mathrm{AMH})$ gene promoter and $\mathrm{AMH}$ protein expression in patients with the Mayer-Rokitanski-Kuster-Hauser syndrome. Human Reproduction 20 149-157. (doi:10.1093/humrep/deh547)

Oppenheim RW 1991 Cell death during development of the nervous system. Annual Review of Neuroscience 14 453-501. (doi:10.1146/ annurev.ne.14.030191.002321)

Orvis GD, Jamin SP, Kwan KM, Mishina Y, Kaartinen VM, Huang S, Roberts AB, Umans L, Huylebroeck D, Zwijsen A et al. 2008 Functional redundancy of TGF- $\beta$ family type I receptors and receptor-Smads in mediating anti-Müllerian hormone-induced Müllerian duct regression in the mouse. Biology of Reproduction 78 994-1001. (doi:10.1095/ biolreprod.107.066605)

O'Shaughnessy PJ, Hu L \& Baker PJ 2008 Effect of germ cell depletion on levels of specific mRNA transcripts in mouse Sertoli cells and Leydig cells. Reproduction 135 839-850. (doi:10.1530/REP-08-0012)

Oshima M, Oshima H \& Taketo MM 1996 TGF- $\beta$ receptor type II deficiency results in defects of yolk sac hematopoiesis and vasculogenesis. Developmental Biology 179 297-302. (doi:10.1006/dbio.1996.0259)

Pankhurst MW \& McLennan IS 2012 Inhibin B and anti-Müllerian hormone/Müllerian-inhibiting substance may contribute to the male bias in autism. Translational Psychiatry 2 e148. (doi:10.1038/tp.2012.72)

Pankhurst MW \& McLennan IS 2013 Human blood contains both the uncleaved precursor of anti-Müllerian hormone and a complex of the NH2and COOH-terminal peptides. American Journal of Physiology. Endocrinology and Metabolism 305 E1241-E1247. (doi:10.1152/ajpendo.00395.2013)

Pankhurst MW, Chong YH \& McLennan IS 2014 Enzyme-linked immunosorbent assay measurements of antiMüllerian hormone (AMH) in human blood are a composite of the uncleaved and bioactive cleaved forms of AMH. Fertility and Sterility 101 846-850. (doi:10.1016/j. fertnstert.2013.12.009)

Park C, Lavine K, Mishina Y, Deng CX, Ornitz DM \& Choi K 2006 Bone morphogenetic protein receptor 1 A signaling is dispensable for hematopoietic development but essential for vessel and atrioventricular endocardial cushion formation. Development 133 3473-3484. (doi:10.1242/dev.02499)

Pask AJ, Whitworth DJ, Mao CA, Wei KJ, Sankovic N, Graves JA, Shaw G, Renfree MB \& Behringer RR 2004 Marsupial anti-Müllerian hormone gene structure, regulatory elements, and expression. Biology of Reproduction 70 160-167. (doi:10.1095/biolreprod.103.020016)
Pask AJ, Calatayud NE, Shaw G, Wood WM \& Renfree MB 2010 Oestrogen blocks the nuclear entry of SOX9 in the developing gonad of a marsupial mammal. BMC Biology 8 113. (doi:10.1186/1741-7007-8-113)

Pepinsky RB, Sinclair LK, Chow EP, Mattaliano RJ, Manganaro TF, Donahoe PK \& Cate RL 1988 Proteolytic processing of Müllerian inhibiting substance produces a transforming growth factor- $\beta$-like fragment. Journal of Biological Chemistry 263 18961-18964.

Pieretti-Vanmarcke R, Donahoe PK, Szotek P, Manganaro T, Lorenzen MK, Lorenzen J, Connolly DC, Halpern EF \& MacLaughlin DT 2006 Recombinant human Müllerian inhibiting substance inhibits longterm growth of MIS type II receptor-directed transgenic mouse ovarian cancers in vivo. Clinical Cancer Research 12 1593-1598. (doi:10.1158/ 1078-0432.CCR-05-2108)

Poonlaphdecha S, Pepey E, Huang SH, Canonne M, Soler L, Mortaji S, Morand S, Pfennig F, Melard C, Baroiller JF et al. 2011 Elevated amh gene expression in the brain of male tilapia (Oreochromis niloticus) during testis differentiation. Sexual Development 5 33-47. (doi:10.1159/000322579)

Ragin RC, Donahoe PK, Kenneally MK, Ahmad MF \& MacLaughlin DT 1992 Human Müllerian inhibiting substance: enhanced purification imparts biochemical stability and restores antiproliferative effects. Protein Expression and Purification 3 236-245. (doi:10.1016/10465928(92)90020-W)

Rajpert-De Meyts E, Jorgensen N, Graem N, Muller J, Cate RL \& Skakkebaek NE 1999 Expression of anti-Müllerian hormone during normal and pathological gonadal development: association with differentiation of Sertoli and granulosa cells. Journal of Clinical Endocrinology and Metabolism 84 3836-3844.

Renaud EJ, MacLaughlin DT, Oliva E, Rueda BR \& Donahoe PK 2005 Endometrial cancer is a receptor-mediated target for Müllerian inhibiting substance. PNAS 102 111-116. (doi:10.1073/pnas.0407772101)

Rey RA, Belville C, Nihoul-Fekete C, Michel-Calemard L, Forest MG, Lahlou N, Jaubert F, Mowszowicz I, David M, Saka N et al. 1999 Evaluation of gonadal function in 107 intersex patients by means of serum antiMüllerian hormone measurement. Journal of Clinical Endocrinology and Metabolism 84 627-631.

Ricci M, Mohapatra B, Urbiztondo A, Birusingh RJ, Morgado M, Rodriguez MM, Lincoln J \& Vatta M 2010 Differential changes in TGF- $\beta$ /BMP signaling pathway in the right ventricular myocardium of newborns with hypoplastic left heart syndrome. Journal of Cardiac Failure 16 628-634. (doi:10.1016/j.cardfail.2010.03.007)

Schwindt B, Doyle LW \& Hutson JM 1997 Serum levels of Müllerian inhibiting substance in preterm and term male neonates. Journal of Urology 158 610-612. (doi:10.1016/S0022-5347(01)64569-5)

Segev DL, Ha TU, Tran TT, Kenneally M, Harkin P, Jung M, MacLaughlin DT, Donahoe PK \& Maheswaran S 2000 Müllerian inhibiting substance inhibits breast cancer cell growth through an NFkB-mediated pathway. Journal of Biological Chemistry 275 28371-28379. (doi:10.1074/jbc.M004554200)

Segev DL, Hoshiya Y, Stephen AE, Hoshiya M, Tran TT, MacLaughlin DT, Donahoe PK \& Maheswaran S 2001 Müllerian inhibiting substance regulates NFKB signaling and growth of mammary epithelial cells in vivo. Journal of Biological Chemistry 276 26799-26806. (doi:10.1074/ jbc.M103092200)

Segev DL, Hoshiya Y, Hoshiya M, Tran TT, Carey JL, Stephen AE, MacLaughlin DT, Donahoe PK \& Maheswaran S 2002 Müllerianinhibiting substance regulates NF- $\mathrm{B}$ signaling in the prostate in vitro and in vivo. PNAS 99 239-244. (doi:10.1073/pnas.221599298)

Seidah NG, Khatib AM \& Prat A 2006 The proprotein convertases and their implication in sterol and/or lipid metabolism. Biological Chemistry $\mathbf{3 8 7}$ 871-877. (doi:10.1515/BC.2006.110)

Settle SH Jr, Rountree RB, Sinha A, Thacker A, Higgins K \& Kingsley DM 2003 Multiple joint and skeletal patterning defects caused by single and double mutations in the mouse Gdf6 and Gdf5 genes. Developmental Biology 254 116-130. (doi:10.1016/S0012-1606(02)00022-2)

Shand AW, Whitton K, Pasfield A, Nassar N, McShane M, Han X \& Henry A 2014 Evaluation of anti-Müllerian hormone in the first trimester as a predictor for hypertensive disorders of pregnancy and other adverse 
pregnancy outcomes. Australian \& New Zealand Journal of Obstetrics \& Gynaecology 54 244-249. (doi:10.1111/ajo.12183)

Shi Y \& Massague J 2003 Mechanisms of TGF- $\beta$ signaling from cell membrane to the nucleus. Cell 113 685-700. (doi:10.1016/S00928674(03)00432-X)

Shoemaker C, Ramsey M, Queen J \& Crews D 2007 Expression of Sox9, Mis, and Dmrt1 in the gonad of a species with temperature-dependent sex determination. Developmental Dynamics 236 1055-1063. (doi:10.1002/ dvdy.21096)

Shull MM, Ormsby I, Kier AB, Pawlowski S, Diebold RJ, Yin MY, Allen R, Sidman C, Proetzel G, Calvin D et al. 1992 Targeted disruption of the mouse transforming growth factor- $\beta 1$ gene results in multifocal inflammatory disease. Nature 359 693-699. (doi:10.1038/359693a0)

Smeyne RJ, Klein R, Schnapp A, Long LK, Bryant S, Lewin A, Lira SA \& Barbacid M 1994 Severe sensory and sympathetic neuropathies in mice carrying a disrupted Trk/NGF receptor gene. Nature 368 246-249. (doi:10.1038/368246a0)

Smith CA \& Sinclair AH 2004 Sex determination: insights from the chicken. BioEssays 26 120-132. (doi:10.1002/bies.10400)

Smith CA, Smith MJ \& Sinclair AH 1999 Gene expression during gonadogenesis in the chicken embryo. Gene 234 395-402. (doi:10.1016/S0378-1119(99)00179-1)

Stawowy P, Marcinkiewicz J, Graf K, Seidah N, Chretien M, Fleck E \& Marcinkiewicz M 2001 Selective expression of the proprotein convertases furin, pc5, and pc7 in proliferating vascular smooth muscle cells of the rat aorta in vitro. Journal of Histochemistry and Cytochemistry 49 323-332. (doi:10.1177/002215540104900306)

Takahashi A \& Mizusawa K 2013 Posttranslational modifications of proopiomelanocortin in vertebrates and their biological significance. Frontiers in Endocrinology 4 143. (doi:10.3389/fendo.2013.00143)

Taketo T, Saeed J, Manganaro T, Takahashi M \& Donahoe PK 1993 Müllerian inhibiting substance production associated with loss of oocytes and testicular differentiation in the transplanted mouse XX gonadal primordium. Biology of Reproduction 49 13-23. (doi:10.1095/ biolreprod49.1.13)

Tilleman H, Hakim V, Novikov O, Liser K, Nashelsky L, Di Salvio M, Krauthammer M, Scheffner O, Maor I, Mayseless O et al. 2010 Bmp5/7 in concert with the mid-hindbrain organizer control development of noradrenergic locus coeruleus neurons. Molecular and Cellular Neurosciences 45 1-11. (doi:10.1016/j.mcn.2010.05.003)

Tran D, Picard JY, Campargue J \& Josso N 1987 Immunocytochemical detection of anti-Müllerian hormone in Sertoli cells of various mammalian species including human. Journal of Histochemistry and Cytochemistry 35 733-743. (doi:10.1177/35.7.3295030)

Uhrin P, Schofer C, Zaujec J, Ryban L, Hilpert M, Weipoltshammer K, Jerabek I, Pirtzkall I, Furtmuller M, Dewerchin M et al. 2007 Male fertility and protein $\mathrm{C}$ inhibitor/plasminogen activator inhibitor-3 (PCI): localization of PCI in mouse testis and failure of single plasminogen activator knockout to restore spermatogenesis in PCI-deficient mice. Fertility and Sterility 88 1049-1057. (doi:10.1016/ j.fertnstert.2006.11.193)

Veinot JP, Prichett-Pejic W, Picard P, Parks W, Schwartz R, Seidah NG \& Chretien M 2004 Implications of proprotein convertase 5 (PC5) in the arterial restenotic process in a porcine model. Cardiovascular Pathology 13 241-250. (doi:10.1016/j.carpath.2004.05.004)

Vigier B, Legeai L, Picard JY \& Josso N 1982 A sensitive radioimmunoassay for bovine anti-Müllerian hormone, allowing its detection in male and freemartin fetal serum. Endocrinology 111 1409-1411. (doi:10.1210/ endo-111-4-1409)

Villeneuve P, Seidah NG \& Beaudet A 1999 Immunohistochemical distribution of the prohormone convertase PC5-A in rat brain. Neuroscience 92 641-654. (doi:10.1016/S0306-4522(98)00763-5)
Visser JA, Durlinger AL, Peters IJ, van den Heuvel ER, Rose UM, Kramer P, de Jong FH \& Themmen AP 2007 Increased oocyte degeneration and follicular atresia during the estrous cycle in anti-Müllerian hormone null mice. Endocrinology 148 2301-2308. (doi:10.1210/en.2006-1265)

Visser JA, Schipper I, Laven JS \& Themmen AP 2012 Anti-Müllerian hormone: an ovarian reserve marker in primary ovarian insufficiency. Nature Reviews. Endocrinology 8 331-341. (doi:10.1038/nrendo.2011.224)

Wang PY, Koishi K, McGeachie AB, Kimber M, Maclaughlin DT, Donahoe PK \& McLennan IS 2005 Müllerian inhibiting substance acts as a motor neuron survival factor in vitro. PNAS 102 16421-16425. (doi:10.1073/pnas.0508304102)

Wang PY, Koishi K \& McLennan IS 2007 BMP6 is axonally transported by motoneurons and supports their survival in vitro. Molecular and Cellular Neurosciences 34 653-661. (doi:10.1016/j.mcn.2007.01.008)

Wang J, Dicken C, Lustbader JW \& Tortoriello DV 2009a Evidence for a Müllerian-inhibiting substance autocrine/paracrine system in adult human endometrium. Fertility and Sterility 91 1195-1203. (doi:10.1016/ j.fertnstert.2008.01.028)

Wang PY, Protheroe A, Clarkson AN, Imhoff F, Koishi K \& McLennan IS $2009 b$ Müllerian inhibiting substance contributes to sex-linked biases in the brain and behavior. PNAS 106 7203-7208. (doi:10.1073/pnas. 0902253106)

Wang Y, Wang XH, Fan DX, Zhang Y, Li MQ, Wu HX \& Jin LP 2014 PCSK6 regulated by $\mathrm{LH}$ inhibits the apoptosis of human granulosa cells via activin A and TGF $\beta 2$. Journal of Endocrinology 222 151-160. (doi:10.1530/JOE-13-0592)

Western PS, Harry JL, Graves JA \& Sinclair AH 1999 Temperature-dependent sex determination in the American alligator: AMH precedes SOX9 expression. Developmental Dynamics 216 411-419. (doi:10.1002/ (SICI)1097-0177(199912)216:4/5\%3C;411::AID-DVDY9\%3E;3.0.CO;2-Y)

Wilson CA, di Clemente N, Ehrenfels C, Pepinsky RB, Josso N, Vigier B \& Cate RL 1993 Müllerian inhibiting substance requires its N-terminal domain for maintenance of biological activity, a novel finding within the transforming growth factor- $\beta$ superfamily. Molecular Endocrinology 7 247-257.

Wittmann W \& McLennan IS 2011 The male bias in the number of Purkinje cells and the size of the murine cerebellum may require Müllerian inhibiting substance/anti-Müllerian hormone. Journal of Neuroendocrinology 23 831-838. (doi:10.1111/j.1365-2826.2011.02187.x)

Wittmann W \& McLennan IS 2013a Anti-Müllerian hormone may regulate the number of calbindin-positive neurons in the sexually dimorphic nucleus of the preoptic area of male mice. Biology of Sex Differences 418 . (doi:10.1186/2042-6410-4-18)

Wittmann W \& McLennan IS $2013 b$ The bed nucleus of the stria terminalis has developmental and adult forms in mice, with the male bias in the developmental form being dependent on testicular AMH. Hormones and Behavior 64 605-610. (doi:10.1016/j.yhbeh.2013.08.017)

Wu X, Arumugam R, Baker SP \& Lee MM 2005 Pubertal and adult Leydig cell function in Müllerian inhibiting substance-deficient mice. Endocrinology 146 589-595. (doi:10.1210/en.2004-0646)

Wu GC, Chiu PC, Lyu YS \& Chang CF 2010 The expression of amh and amhr2 is associated with the development of gonadal tissue and sex change in the protandrous black porgy, Acanthopagrus schlegeli. Biology of Reproduction 83 443-453. (doi:10.1095/biolreprod.110.084681)

Xavier F \& Allard S 2003 Anti-Müllerian hormone, $\beta$-catenin and Müllerian duct regression. Molecular and Cellular Endocrinology 211 115-121. (doi:10.1016/j.mce.2003.09.022)

Yarde F, Maas AH, Franx A, Eijkemans MJ, Drost JT, van Rijn BB, van Eyck J, van der Schouw YT \& Broekmans FJ 2014 Serum AMH levels in women with a history of preeclampsia suggest a role for vascular factors in ovarian aging. Journal of Clinical Endocrinology and Metabolism 99 579-586. (doi:10.1210/jc.2013-2902)

Received in final form 6 July 2015

Accepted 10 July 2015

Accepted Preprint published online 10 July 2015 http://joe.endocrinology-journals.org

DOI: $10.1530 / J O E-15-0206$
(C) 2015 Society for Endocrinology Printed in Great Britain
Published by Bioscientifica Ltd 